\title{
민간부문(기업)과 Post-Busan 국제개발협력
}

오 주 현 (KOICA 민관협력실 과장)

\section{목 차}

1. 들어가며

2. 지속가능한 경영과 Post-Busan 이행체제

3. 국내기업의 개발협력 활동 참여방안

4. 나가며 : 향후 추진과제

\section{1. 들어가며}

한국은 2009년 12월 경제협력개발기구(Organization for Economic Cooperation and Development : OECD) 산하 개발원조위원회(Developement Assistance Committee : $\mathrm{DAC}$ )에 가입하였고, 2011년 11월 부산에서 원조효과성에 대한 4차 고위급회의를 개최하였다. 이처럼 한국은 국제개발협력 무대에서 주요한 공여국으로 도약하고 있으며, 부산에서 개최된 $\mathrm{HLF}-4$ 는 한국이 개발협력 분야를 이끌어 나가기 위한 방향성을 제시하는 계기가 되었을 뿐만 아니라 국제개발협력에 대한 이해를 증진시킬 수 있는 기회를 제공했다는 측면에서 앞으로 한 국의 국제개발협력의 빠른 성장에 기여할 것으로 보인다.

2011년 부산 세계개발원조총회에서 국제사회는 개발협력 효과성을 제고할 수 있는 부산 글로 벌 파트너십1) 운영방안 및 평가지표, 그리고 모니터링 체제를 개발하기로 합의하였다.

1) 국제사회는 부산총회 이후 체제를 '글로벌 파트너십(the Global Partnership)'이라고 공식적으로 명시하기로 하였음 (임소진, 2012b). 
이에 세 차례에 걸친 Post-Busan 임시그룹(Post-Busan Interim Group)회의의 내용을 반 영하여, 2012년 6월 원조효과작업반 회의에서 부산 글로벌 파트너십 운영방안과 평가지표, 모 니터링 체제가 최종 합의되었다.

\section{〈부산 글로벌 파트너십 10대 평가지표〉2)}

지표 1. 개도국 우선사항을 충족하는 결과중심의 협력

지표 2. 개발활동의 참여와 기여를 최대화하는 환경에서의 시민사회 운영

지표 3. 개발을 위한 민간부문의 참여와 기대

지표 4. 투명성 : 개발협력에 관한 정보 공개

지표 $5 \mathrm{a}$. 개발협력 예측성(1년)

지표 $5 \mathrm{~b}$. 개발협력 예측성(중기)

지표 6. 의회의 정밀검토에 따른 정부의 원조예산

지표 7. 포괄적 검토에 의한 개발협력 주체간 상호책무성 강화

지표 8. 양성평등과 여성지위향상

지표 $9 \mathrm{a}$. 개도국 공공재정 $(\mathrm{PFM})$ 시스템의 질

지표 $9 \mathrm{~b}$. 개도국 $\mathrm{PFM}$ 시스템 및 공공조달시스템 이용

지표 10. 원조비구속성

사실 부산 글로벌 파트너십 체계를 제대로 이해하기 위해서는 선행되었던 파리선언에 대한 이 행결과를 점검해보지 않을 수 없다. 결론적으로 국제사회의 파리선언 이행결과, 총 13 개 세부지 표 중 지표 4만이 달성되었다 $(\mathrm{OECD}, 2011)$. 파리선언 이행목표 달성에 실패한 주요한 이유를 살펴보면, 현실적으로 불가능한 시간적 이행목표(2005 2010), 유럽 선진공여국 중심의 지표개 발, 공여국의 정치적 의지 부족 및 행동변화 미약, 국별로 상이한 지표해석, 개도국 시스템 개발 역량 부족에 대한 미흡한 고려 및 원조 이행과정에서 지나치게 기술적인 측면을 강조한 것으로 요약될 수 있다 (임소진, 2012a).

한국은 파리선언 이행과정에서 모든 지표에서 목표를 달성하지 못했으나, 이는 한국의 법제적 시스템과 현실적인 요소에 의해 파리선언 이행이 용이하지 않았던 것으로 파악되고 있다. 따라 서, 향후 부산파트너십 지표 이행 및 모니터링 참여시에는 체계적이고 적절한 정책 및 전략제시 가 필요할 것이다.

2) 임소진, 2012b 
우선 부산파트너십 지표개발을 위한 Post-Busan 임시그룹(Post-Busan Interim Group, 이후 PBIG)에서 논의된 부산지표 개발의 주요방향으로는 유럽의 선진공여국 중심으로 개발된 파리지표의 한계를 극복하기 위해, 부산파트너십 지표 개발과정에서는 유럽중심의 공여국 뿐 아니라 개도국과 신흥공여국, 시민사회의 의견을 적극 반영하였다는 점이다 (임소진, 2012b).

더불어, 금번 부산총회에서는 ODA(Official Development Assistance) 재원에 대한 financing channel의 다변화 및 ODA에 민간부문의 효율성 도입차원에서 민간부분3)의 역할 이 강조되었다는 점과 이를 위해 부산지표 제 3 에 관련 지표(상기 부산 글로벌 파트너십 10 대 평가지표 참고)가 제시되었다는 점에 주목할 필요가 있다.

이는 기업의 영향력이 확대됨에 따라 사회적 책임(CSR: Corporate Social Responsibility) 에 대한 대내외적 요구가 증가하고, 전 세계가 당면한 글로벌 도전과제를 해결하는 데 있어 지 속가능한 경영에 대한 관심이 크게 증가하고 있는 사회적 현상을 반영하고 있다고 볼 수 있다.

그러나, 기업의 지속가능한 성장을 유도하는 차원에서 민간부분의 $\mathrm{ODA}$ 에 대한 참여는 민간 부분의 전략적 목표인 동시에 사회 문제의 적극적 해결방안을 제시하며 국가 차원의 지속가능 한 발전을 촉진하는 중요한 매개체 역할을 해야 할 것이다. 더 나아가, 민간부분을 활용하여 산 업 전반에 지속가능한 발전을 확산시키기 위해 통합적 접근법을 고려해야 할 것이다.

본고에서는 부산총회이후 Post-Busan 체제의 효과적인 이행을 위해 민간부분의 역할과 가 능한 참여방안에 대해 살펴보고, 향후 KOICA 활동과 연계할 수 있는 방안에 대해 모색해 보고 자 한다.

\section{2. 지속가능한 경영과 Post-Busan 이행체제}

부산총회를 계기로 한국의 $\mathrm{ODA}$ 의 양적 확대 및 질적 개선은 한국에 새로운 기회이자 위기이 기도 하다. 우선 $\mathrm{ODA}$ 가 확대됨에 따라 우리 기업들이 $\mathrm{ODA}$ 시장에 참여할 수 있는 기회가 점 차 확대될 전망이다. 전 세계의 연간 $\mathrm{ODA}$ 조달시장 규모는 약 1,360 억불 규모로 앞으로 우리

3) 본고에서 민간은 private sector(기업)를 의미하는 것으로 시민사회(civil society)는 포함되지 않음. 
$\mathrm{ODA}$ 사업의 경험을 바탕으로 국제 $\mathrm{ODA}$ 사업의 참여기회가 확대될 것이다 (이계우, 2009). 이 와 관련하여, 국제개발협력 선진화 방안에서는 국제개발협력의 기반확대를 위하여 '국민과 함 께하는 개발협력' 의 일환으로 ' $\mathrm{NGO}$, 민간기업, 대학 및 연구기관 등과 협력' 등을 제시하고 있 어 앞으로 민간부분의 $\mathrm{ODA}$ 참여확대를 기대해 볼만하다.

그간 국제개발협력 분야에서는 새천년개발목표(MDGs) 달성뿐만 아니라, 전 지구적 발전과 국제협력을 위해서 국내자금, 민간자금, $\mathrm{ODA}$, 투자 등 다양한 형태로 개발재원의 확보가 필요 하다는 공동의 인식하에 ‘몬테레이 합의' (Monterrey Consensus)를 채택하였다. 그러나, 개도 국으로 이전된 개발재원에서 공적원조가 차지하는 비중은 지난 20 년간 $69.4 \%$ 에서 $31.6 \%$ 로 반 감되었다 (곽재성, 2012). 이러한 점이 시사하는 바는 $\mathrm{ODA}$ 의 총량이 상당히 증가했음을 감안 하면 민간부문의 중요성이 매우 커졌다는 것을 알 수 있다.

\section{지속가능한 발전(Sustainable Development)}

1980년대 이후, 단순한 환경보전의 차원을 넘어 경제성장과 사회발전을 동시에 이루고자 하 는 지속가능한 발전(Sustainable Development)을 위한 국제사회의 노력이 가속화 되었다. 즉, 글로벌화가 가속화되면서 사회에 미치는 기업의 영향력이 확대됨에 따라, 기업의 사회적 책 임 이행이 지속가능한 발전을 견인하는 중추적 역할을 담당하게 된 것이다. 더불어, 기후변화, 생태계 파괴, 빈곤, 불평등 등 오늘날의 범지구적 도전에 보다 효율적으로 대처하기 위해서는 기업의 지속가능한 경영 활동이 보다 강화되고 있는 추세라고 할 수 있다.

민간의 활발한 개발사업 참여는 공적원조와는 달리 기업의 경영목표를 이룩하고 비즈니스 활 성화를 통해 개도국의 경제도 성장시킬 수 있다는 점에서 지극히 매력적인 것으로 보인다. 다양 한 연구결과에 따르면, 지속가능 경영은 기업의 재무적 성과, 나아가 기업의 경쟁력에 긍정적인 상관관계를 보인다.

- Mile \& Covin (2000)은 기업의 이미지나 명성을 나타내는 포츈(Fortune)의 기업명성지수 (Corporate Reputation Index)를 사용하여 기업의 경제적 가치와의 연관성을 실증 분석 한 결과, 기업명성지수와 수익성 사이에는 양의 상관관계가 있음을 입증함.

- 다우존수 지속가능성지수(DJSI:Dow Jones Sustainability Index)4)와 글로벌 주가지수 인 모건스탠리 지수(MSCI:Morgan Stanley Capital International Index) ${ }^{5)}$ 의 수익률을 비교해 보면, DJSI의 평균 수익률이 MSCI보다 높은 수익률을 보이고 있음.

이러한 관점에서 지속가능경영(Sustainable Management)과 기업의 사회적 책임성은 여러 
각도에서 주목받고 있으며, 국제개발에서 민간의 역할과 기능에 대한 관심이 증폭되고 있는 것 이다.

지속가능경영은 정부·기업·시민사회를 연결하는 하나의 관계시스템(Relational System) 으로 파트너십 이니셔티브를 통한 사회문제 해결의 실마리를 제공한다 (Buckland et al., 2006). Zadek (2001)에 의하면, 자선활동에서 시작된 기업의 사회적 책임 활동은 그 영역이 점 차 확대되어 시민사회와 정부와의 파트너십을 통해 '지속가능성' 을 향한 활동으로 발전하여 사 회문제의 적극적인 해결책을 제시한다.

\section{〈지속가능경영 발전과정〉6)}

\section{-1세대 : 자선활동(Corporate philanthropy)}

- 물품기증, 봉사활동 참여 등 기업의 이익을 저해하지 않는 범위에서 사회적 책임활동을 수행

\section{- 2세대 : 중장기 경영 전략의 필수요소}

- 지속가능경영의 긍정적 효과를 인식, 기업의 중장기 경영 전략의 핵심 요소로 지속적이고 체계적으로 추진

\section{-3세대 : 사회문제 해결에 기여(빈곤, 소외, 환경문제)}

- 시민사회와 정부와의 파트너십을 통해 '지속가능성' 을 향한 활동으로 발전

지속가능경영은 지구환경을 보전하기 위한 지속가능한 발전(Sustainable Development)에 근간을 두고 있다. 1987년 세계환경개발위원회(WCED; World Commission for Environment and Development)가 발표한 'Our Common Future'란 보고서에서' 환경적 으로 건전하고 지속가능한 발전(Environmentally Sound and Sustainable Development)' 이란 개념으로 제시되어, 1992년 유엔환경개발회의(UNCED; UN Conference on Environment and Development)7)와 2002년 지속가능발전 세계정상회의(WSSD; World Summit of Sustainable Development))를 거치면서 인류가 추구해야할 보편적 개념으로 자

4) 미국의 다우존스(Dow Jones)와 세계적 자산관리사인 스위스 SAM(Sustainable Asset Managment)가 공동으로 발표하는 기업의 사회적 책임을 측정하는 대표적 지수임.

5) 미국의 투자은행인 모건스탠리(Morgan Stanley)의 자회사인 MSCl가 발표하는 세계 주가지수

6) Zadek, 2001 
리 잡았으며, 지속가능성(Sustainability) 개념에 기업의 경영방식을 접목시킨 하나의 경영기 법으로 발전하였다. 2000년 지속가능한 발전을 위한 기업의 사회적 책임에 대한 보편적 원칙인 유엔 글로벌컴팩(UN Global Compact)9)이 출범하면서 지속가능발전에 있어 기업의 참여와 역할이 대두하게 된 것이다.

\section{사회적 책임(CSR, Corporate Social Responsibility)}

지속가능한경영과 유사한 용어로 기업의 사회적 책임을 의미하는 CSR(Corporate Social Responsibility)이 가장 보편적으로 사용되고 있으나, 해당 국가 혹은 기관의 특성에 따라 다양 한 견해가 존재하고 있다.

\section{〈지속가능경영에 대한 정의 및 용어〉}

- EU(유럽연합) : 비즈니스 전략과 기업활동에 사회, 환경에 대한 책임의식을 통합시키는 것 으로 자발성을 바탕으로 이해관계자들과의 지속적인 커뮤니케이션이 이루 어져야 함/CSR

- ICC(국제상공회의소) : 기업이 책임있는 방식으로 기업 활동을 하고자 하는 자발적 의지/CR

- ISO(국제표준화기구) : 조직의 의사결정과 기업 활동이 사회, 환경에 미치는 영향에 관한 자발적 책임/SR

- $\mathrm{OECD}$ (경제개발협력기구) : 기업과 사회의 관계를 발전시키고 지속가능한 발전을 이루기 위한 기업의 행동/CR

-World Bank(세계은행) : 가족, 지역사회 및 사회전체와 협력하여 지속가능한 경제 성장에 기여하고 이해관계자들의 삶의 질을 향상시키고자 하는 기업의 책임의식/CSR

- WBCSD(지속가능발전세계기업협의회) : 근로자, 가족, 지역사회와 사회전반의 삶의 질을 개선시키며 이들과 더불어 지속가능한 경제적 발 전을 하기 위한 기업들의 노력/CSR

7) 1992 년 유엔환경개발회의에서는 환경과 개발에 관한 27 개 원칙으로 구성된 리우선언(The Rio Declaration on Environment and Development)과 실천전략인 의제21(Agenda 21)을 채택하여 지속가능한 발전의 개념이 정착됨.

8) 2002년 남아프리카 요하네스버그에서 개최된 지속가능발전 세계정상회의(WSSD)에서는 국제사회의 지속가능발 전의 추진 실적을 평가하고 향후 구체적인 추진전략을 마련하여 지속가능발전의 실천을 강조함.

9) 기업이 사회적으로 책임을 이행함으로써, 세계화 문제의 해결을 지향하고 인권, 노동, 환경, 반부패 등 4 가지 범주에 대한 10 개 원칙을 준수, 실천하도록 권고하는 국제적 협약임. 
1960년대까지는 기업의 이윤추구가 우선시 되는 '소극적 CSR'이 대부분이였으며, 이후에는 기업 활동으로 인한 역기능의 해결과 이미지 개선을 위해' 방어적 CSR '을 시행하였다면, 2000 년대 이후에는 '공동가치의 창조(Creating Shared Value: CSV)를 위한 '전략적 CSR' 이 정 착되어가고 있다고 볼 수 있다. 이처럼 기업들의 해외 CSR이 중요한 이슈로 부각한 데에는 몇 가지 거시적 변화에 기인한다 (곽재성, 2012).

- 글로벌화 및 신자유주의로 인해 민간기업의 활동이 사회전반에 미치는 영향력 확대

- 기후변화, 환경문제 및 지속가능성에 대한 중요성 대두10)

- 기업을 보는 시각의 변화

정보화의 발달로 기업의 부도덕한 경영활동, 부정적 성과 등에 대한 정보가 전 세계 소비자에 게 순식간에 전파되어 기업의 제품 판매 하락 뿐 아니라 기업명성에 치명적인 영향을 미치고 있 다. 예를 들어, 월마트(Walmart)의 저가 제품 공급이 해외에서의 노동력 착취, 환경오염 등을 기반으로 했다는 사실이 언론을 통해 공개되자, 각종 시민단체들은 인터넷을 통해 해외 저임금 근로자의 비참한 실상을 파헤쳤고, 이로 인해 월마트의 부정적 이미지는 세계로 확산되었다.

또한, 기업의 지속가능경영 적용 범위가 원재료 및 부품 조달에 이르기까지 공급망 전반으로 확대되고 있다는 점이다. 조달부품의 일부가 국제적 수준 혹은 해당국의 지속가능경영 준수 기준 에 이르지 못할 경우 거래가 중단되거나 시장기회를 놓치는 사례가 빈번히 발생한다는 것이다.

게다가, 기업 활동에 대한 이해관계자들의 관심이 크게 증대하고 있어, 소비자, 시민단체 등 다양한 이해관계자들이 제품의 가격, 품질 이외에도 기업의 환경 - 사회적 책임활동에 대해서도 높은 관심을 가지고 있다는 사실을 주목해야 할 것이다.

\section{〈기업의 CSR활동에 영향을 미치는 이해관계자 가치관의 변화〉11)}

\section{- 주주 및 투자가}

- 사회적 책임투자(SRI)의 확대

- 투자행동, 주주행동에 사회성 배려

10) 1987 년 UN의 '환경과 개발에 관한 세계위원회' 의 보고서인 'Our Common Future'(일명 브란트란트 보고서)에 서 '지속가능한 개발 '에 관한 개념이 탄생한 이후 인류사회의 생존과 번영을 위한 새로운 개발 패러다임에 대한 인식이 강화되고 있음.

11) 이부키 에이코, 2006 
- 소비자

- 사회성을 배려한 제품·서비스의 적극적인 구매

- 반사회적 제품·서비스의 보이콧

- 거래처

- 기업간 거래 및 행정에 사회성 고려

\section{- 종업원}

- 사회성 중시하는 기업선호

- 노동환경, 고용책임에 대한 적극적인 항의행동

\section{- 지역사회}

- 활발한 기업의 사회성 평가

- NGO의 강력한 항의행동

\section{민간부문과 Post-Busan 이행체계}

기업은 이미 해외직접투자(FDI)를 통하여 개도국의 개발에 엄청난 영향을 미치고 있다.

Michael Hopkins에 따르면 CSR에는 아래와 같은 형태의 종류로 구분된다 (Hopkins, 2007).

- Type I : 개도국내 좋은 목적을 위한 자선적 기부

- Type II : 개도국을 위한 새로운 상품 개발 - 판매, 개도국내 투자

- Type III : 개도국의 지속가능한 성장과 빈곤퇴치를 위한 CSR활동

상기에 언급된 CSR의 형태는 지속가능경영 발전과정과 유사한 형태를 띠며, Type III는 Type I 보다 영향이 크고 장기적으로 지속가능한 성장에 도움을 주어 기업은 브랜드가치를 높 일 수 있게 된다. 이처럼 기업의 CSR은 지속가능한 발전에 기여한다는 측면에서 개발협력에서 주요한 담론으로 언급되고 있는 '지속가능성' 과 연계된다. 이러한 관점에서 기업의 CSR을 효 과성 높은 개발재원으로 어떻게 활용할 것인가에 대한 고민이 향후 부산파트너십 체제 하에 '효 과적인 개발협력 을 이행하기 위한 근간이 될 것이다.

부산총회에서는 개발에 있어서 민간분야의 역할에 대해서도 논의되었는데, 특히 혁신 주도, 부와 소득 및 일자리 창출, 국내 재원의 동원, 빈곤퇴치에 있어 민간부문의 역할이 강조되었다. 나아가 부산결과문(BOD: Busan Outcome Document)에서는 개발협력에서 민간분야 역할을 활성화하기 위해 다음의 사항을 위해 노력할 것을 결의하였다 (임소진, 2011). 
- 민간투자 개발을 위한 법적, 규제적, 행정적 환경을 향상시키기 위한 비즈니스 협회 및 노 동조합 등의 대표들과의 연계(engage) 및 민간부문 개발, 증가된 외국인 직접투자(foreign direct investment, FDI), 민관 파트너십(public-private partnership, PPP), 가치사슬 (value chain)의 강화 등을 위한 건전한 정책 및 규제적 환경 보장

- 지속가능한 성장과 빈곤퇴치를 위한 개발정책과 전략의 설립 및 이행단계에서 민간분야의 참여확대

- 공동의 개발목표를 위한 민간재원을 동원하기 위한 혁신적 금융체계의 발전 심화

- 지속가능한 발전을 위한 '무역을 위한 원조(aid for Trade)' 장려

- 개발과 사업성과(business outcomes)를 증진시키는 방법 모색을 통해 상호 보강효과를 누릴 수 있도록 민 · 관분야의 대표 및 관련 기관의 대표를 개발협력의 주체로 참여 장려 (invite)

사실 아직까지 기업의 개발협력분야에서의 역할에 대한 의미가 불분명한 것이 사실이다. 그럼 에도 불구하고 민간부분을 활용한 협력은 국제개발협력분야의 주요한 담론으로 여겨지고 있다.

게다가 시민사회에서는 개발정책 수립과 이행에서 민간기업의 역할에 대한 지나친 강조와 개 발과 기업의 이윤추구 활동을 상호보완적인 것으로 이해하고 '무역을 위한 원조(Aid for Trade)' 등 수출 주도 성장 이데올로기를 부산총회 결과문서 32 항에서 지나치게 강조하고 있다 며 심각한 우려를 표명하기도 했다 (이성훈, 2011).

부산총회를 계기로 개발효과성 의제가 부각되면서 원조를 기술적 이슈가 아닌 가난퇴치를 위 한 MDGs, 개발재원의 다양화, 경제개발 패러다임 등 국제 정치경제 구조 영역으로 확대하였다 (이성훈, 2012).

부산결과문에서 언급된 민간부문의 역할을 제대로 이행하기 위해서는 향후 기업이 $\mathrm{OECD}$ 의 다국적 가이드라인, 유엔 인권이사회의 기업과 인권에 관한 가이드라인과 프레임워크, 글로벌 컴팩의 10 가지 원칙 및 ISO26000 등 기업의 활동이 국제적 규범에 따라 이루어 질 수 있도록 노력해야 할 것이며, 정부 및 시민사회도 책무성을 제고하는 차원에서 감시하고 견인하는 역할 을 수행해야 할 것이다. 
향후 민간분야의 개발참여 이슈는 Post-Busan 이행체계를 이끄는 중요한 Building Block 으로 각국 정부, 민간기관의 참여 및 리더십에 의해 협력프로세스를 만들어 낼 것이다. 향후 자 발적인 참여를 기초로 비공식 정보공유 활성화를 위한 정책대화 플랫폼을 설치하기 위한 논의 가 이루어질 것이다.

향후 민간부문과의 협력을 통한 개발 및 원조효과성을 극대화하기 위해서는 개발성과 달성을 위해 변화하는 글로벌 개발체제에 부합한 민간기업의 역할에 대한 정의가 필요할 것이며, 지속 적으로 민간분야의 개도국 개발 참여를 독려하기 위한 지원책을 발굴해야 할 것이다.

\section{3. 국내기업의 개발협력 활동 참여방안}

최근 비즈니스 환경변화에 따라 지속가능경영에 대한 실천의 당위성이 더욱 높아져 가고 있 다. 기업의 전략과 통합되어 기업의 국제경쟁력 확보 및 사회 전반의 지속가능한 발전을 도모하 는 측면으로 그 접근 범위가 확대되고 있다는 것이다.

기업을 둘러싼 다양한 이해관계자들이 가지는 기업의 책임 이행에 대한 기대는 규범적 차원으 로 발전하여, 기업은 이제 더 이상 지속가능경영을 간과할 수 없게 되었다. 더욱이, 유럽 및 주 요 국가의 지속가능경영 관련 정책 및 프로그램은 기업의 비즈니스 전략과 통합된 지속가능경 영을 매개로 하여 기업 및 국가의 글로벌 경쟁력을 확보하고 전사회적 지속가능성 향상을 꾀하 고 있다.

한국의 경우, 기업의 사회적 책임에 대한 명확한 인식에 기초하기 보다는 사회적 비판에 대응 하기 위해 지속가능경영을 도입하여 추진하기 시작했다. 급속한 경제발전 후, 1980 년대부터 노 사대립, 인권, 환경문제 등 사회적 이슈가 부각되자 기업들도 사회적 책임에 대한 필요성을 인 식하게 되었고, 1990 년대 이후, 경제단체를 중심으로 윤리강령을 채택하고 해외 진출이 증가함 에 따라 사회공헌활동을 담당하는 전담부서가 신설되었다. 2000년대 들어, 대기업을 중심으로 글로벌 기준에 맞는 지속가능경영 활동을 하기 시작하였으며, 그 일환으로 지속가능경영 보고 서를 발간하고 $\mathrm{NGO}$ 들과 협력 관계를 통해 사회적 이슈에 대해 적극적으로 개입하고 전략적으 로 결과물을 활용하게 되었다. 그러나 대기업과 달리, 자원 및 정보 접근력이 부족한 중소기업 
의 경우 지속가능경영에 대한 인지도가 낮으며 산업 실천기반도 부족한 것으로 나타나 향후 이 에 대한 지원이 필요할 것으로 보인다.

\section{$\langle\mathrm{CSR}$ 의 단계〉12)}

\section{1. 준법정신(Compliance Driven)}

- 준법차원에서 사회에 대한 의무와 양심이 CSR 활동 동기

- CSR 비용지출을 '단순비용' 으로 인식

\section{2. 수익중심(Profit Driven)}

- 재무적 성과 창출을 위해 사회적, 윤리적, 환경적 측면을 기업 경영에 통합하여 CSR을 전략적으로 활용

- CSR비용 지출을 미래 수익을 위한 하나의 '투자' 로 인식

\section{3. 사회복지 중심(Caring Driven)}

- 준법차원과 수익창출을 넘어 경제적, 사회적, 환경적 책임의 조화를 추구

- 주주이익과 함께 사회복지를 위해 경영할 것을 외부에 표명

\section{4. 시너지 단계(Synergical)}

- 모든 이해관계자와의 시너지 효과를 창출하면서 경제적, 사회적, 환경적 가치 창출

- 지속가능성이 주요 전략 목표

\section{5. 기업문화화(Holistic)}

- $\mathrm{CSR}$ 이 기업조직에 전면적으로 통합되고 기업문화로 정착됨

- 지속가능성이 기업활동의 근간이 됨.

더욱이 새천년 개발목표(Millenium Development Goal)의 구체적인 이행방안으로 공공부 문과 민간기업의 협력적 관계구축의 중요성이 대두됨에 따라 기업의 이익을 극대화하면서 국제 적 사회문제를 해결할 수 있는 공공-민간 파트너십 추진이 활발히 논의되었고, 금번 부산 글로 벌 파트너십 체계 하에서도 민간부분의 역할에 대한 중요성이 강조되고 있는 것이다.

12) Van Marrewijk, 2003 
1980년대 복지국가위기론이 대두되면서 사회통합에 있어 민간부문의 역할이 강조되기 시작 하였다. 즉, 사회 구조적 문제는 정부의 개별적 대응보다는 기업과의 공동 접근에 의해 더 효과 적이고 능률적으로 해결할 수 있다는 인식이 확산되면서 공공-민간파트너십(PPP, PublicPrivate Partnership)13)이 등장하게 된 것이다. 이제 국내뿐 아니라 국제적 사회문제 해결과 지속가능한 발전을 위해서는 기업-정부간의 긴밀한 파트너십이 필요하다. 이처럼 공공-민간파 트너십은 기업에게는 사회적 책임 이행의 기회를 제공하고 국가차원의 경쟁력 강화를 위한 방 안이 되고 있다. $\mathrm{OECD/DAC}$ 에서는 공여국과 수원국의 민간투자가 세계경제의 성장과 개발을 촉진시키는 주요 요인이자, 수원국의 고용창출, 빈곤층의 수입증대, 지식이전, 경쟁력 개선, 글 로벌 경제의 효율적인 통합의 계기가 되며, 이는 나아가 빈곤감소와 개도국의 생활환경 개선 및 지속적인 성장에 기여한다고 평가하고 있다.

그렇다면 이처럼 급변하고 있는 상황 속에서 개발을 위한 민간부분의 역할에 대한 효과를 어 떻게 극대화할 수 있을 지에 대해 생각해 봐야 할 것이다. 대체적으로 기업은 개발 관련 정보 또 는 전문성이 부족하고 현지 $\mathrm{NGO}$ 에 대한 관련 정보도 부족한 실정이다. 더불어, 이윤을 창출하 는 기업이라는 특성으로 인해 개도국의 중앙정부 및 지방정부와의 관계 설정이 어려울 수 있다. 현실적인 측면에서는 개발 프로젝트에 대한 투자를 위해 본사를 설득하기 어려운 측면도 있을 것이다. 이러한 점에서 $\mathrm{CSR}$ 과 $\mathrm{ODA}$ 의 연계가 좋은 대안이 될 수 있을 것으로 생각된다.

- 독일 BMZ은 민간부문과 1,400 개의 개발프로젝트 진행

- 미국 USAID는 3,000여 개별 파트너와 1,000 여개의 파트너십 구축

- 덴마크 DANIDA는 2008년까지 300개의 파트너십 구축

$\mathrm{ODA}$ 와 민간부문의 CSR을 연계하는 방법의 사업추진 측면에서는 크게 아래와 같이 크게 세 가지 형태로 구분할 수 있으며,

- Top-down : 구조화된 정부-기업 협력체계 속에서 Top-down 방식으로 진행

-Bottom-up : 기업/시민사회가 연구에 기초하여 local 또는 지역적인 계획과 프로젝트를 기초로 Bottom-up 방식으로 진행

- Result driven : 성과중심의 지속적인 보고와 분석체계

13) 공공-민간파트너십은 사회기반시설(infrastructure) 사업의 개발, 구축, 운영지원 등을 목적으로 하는 공공부문과 민간부문간의 협력형태로 공공서비스의 생산 및 제공에 민간의 관리를 도입하는 접근법을 말함. 
$\mathrm{ODA}$ 와 $\mathrm{CSR}$ 을 연계하는 방식의 이해관계자 참여 측면에서는 아래의 형태로 구분할 수 있을 것이다.

\section{- 일대일 방식(one-to-one approach)}

- 공여국 정부 $1+$ 공여국 기업 1

- 공여국 정부는 자금의 일부, 계약, 개발노하우, 공여국 기업은 경제력, 기술적 전문성, 운 영능력 등 제공

- 복수이해관계자 결합 방식(Multi-Stakeholder initiatives)

- 해결하려는 문제나 필요한 지원의 정도와 범위가 큰 경우, 다수의 행위자 참여

$\mathrm{ex}$ ) 생산부터 소비까지 공급사슬 전체에 대한 관여

\section{- 글로벌 플랫폼(Platforms for achieving global development goals)}

- 보다 광범위한 글로벌 개발목표 달성을 위한 플랫폼 구성

- 공동의 행동을 위해 조정, 노하우 지원 등을 하는 구심체로서 역할

- 변혁적인 파트너십(Transformational Partnerships)

- 다수의 기업과 복수의 이해관계자 참여

- 혁신적인 모델과 방식을 통해 보건제도, 교육제도, 지역적 농업 네트워크 등 시스템전체의 개혁을 추구

상기에 언급된 파트너십 중에 Multi-Stakeholders Initiatives의 좋은 사례가 바로 Competitive African Cotton Initiative(COMPACI)와 Rural Electrification in Africa이 다.

먼저 전자의 경우, 6 개 아프리카 나라의 30만 농민의 생활수준을 향상코자 농민대상 훈련 프 로그램, microcredit, "Cotton Made in Africa"을 운영하였다. 이 프로젝트는 독일 원조집행 기관인 GTZ이 Bill\&Melinda Foundation과 독일 BMZ를 대신해 실행한 것으로 프로젝트 파 트너는 현지 면화생산 기업들이었다. 후자는 프랑스 전력회사(EDF), 네덜란드 에너지 회사 $(\mathrm{NUON})$, 프랑스 회사(TOTAL) 등이 프랑스, 독일, 네덜란드 정부, 세계은행, 아프리카개발은 행 등의 지원으로 농촌지역에 전력을 공급하는 회사(RESCOs)를 설립하여 저비용 태양광 등을 공급하는 프로젝트이다. 이처럼 다양한 형태의 $\mathrm{ODA}$ 와의 연계방식을 통해 민간부문과 협력 관 
계를 구축할 수 있을 것이며, 민간에서도 접근 가능한 모델을 선택하여 콘텐츠를 발전시키는 방 향으로 접근해야 할 것이다.

\section{4. 나가며 : 향후 추진과제}

한국은 부산총회 준비과정에서 민간분야의 참여 제고를 위해 민간포럼을 개최하고, 민간분야 비공식 작업반에 참여하는 등 적극적인 역할을 수행하였다. 이는 민간분야의 이슈가 글로벌 개 발협력사회에서 주요한 이슈로 자리 잡는데 선도적인 역할을 한 것으로 볼 수 있다. 특히,

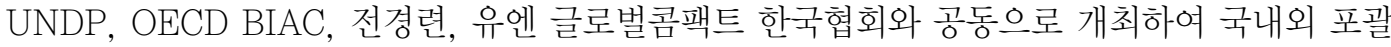
적인 민간분야간 협력할 수 있는 기반을 마련했다는 점에서 의의가 크다. 이러한 민간분야와의 협력에 대한 기조를 유지 및 강화하기 위해서는 Post-Busan 이행체계에서 민간분야의 성과를 지속적으로 관리해 나가는 것이 중요하다.

결국 기업으로 대표되는 민간부문과의 지속가능한 협력체계를 유지하기 위해서는 개도국내에 적절한 '일자리 창출 사업' 과 '기업의 사회적 책임(CSR)'을 연계할 필요성이 있다고 보여진다. 사회적 일자리(사회적 서비스) 확대는 한 국가의 사회적 경제 영역의 확대를 가져오며, 이는 취 업계층의 빈곤탈출 가능성을 높이고 빈곤에 대한 안전망(재빈곤화의 위험성 방지)을 제공할 수 있게 될 것이기 때문이다 (김성규, 2012).

더불어, 개발협력에서 민간부문 활성화를 위한 노력도 병행해야 할 것으로 보인다. 특히 공여 국의 민간부문에 대한 지원을 통해 개도국을 지원하는 논의, 즉 효과적인 공공-민간 파트너십 구축이 필요하다는 공여국 중심의 논의에서 개도국내의 민간부문 활성화를 통해 개선된 사회적 기회 및 안전망을 제공하기 위한 논의가 필요하다. 지금까지 공공-민간파트너십(PPP) 구축을 위한 연구들이 진행이 되었지만, 앞으로는 이러한 연구내용을 바탕으로 개발협력에서 공공-민 간 파트너십 구축을 넘어서 개도국의 사회적 기회 및 안전망 확대를 위한 개도국 민간부문의 비 즈니스와 가치사슬(Value Chain) 형성 사례 연구를 통해 바람직한 파트너십 모델을 제시하는 것이 필요할 것으로 보인다.

이를 위해서는 무엇보다 성공적인 파트너십의 요소를 사전에 검토하여 고려하는 자세가 필요 하다. 즉, 해결하려는 문제가 한쪽 방향으로만은 해결될 수 없다는 것을 인식하고, 문제의 원인 
에 대해 공통의 인식이 선행되어야 할 것이다. 더불어, 지속적으로 전문성과 경험을 교류할 수 있는 네트워크를 구축해야 하고 파트너십이 개별 기관 내에 내재화할 수 있는 시스템을 갖추어 야 할 것이다. 뿐만 아니라, 협력적인 협조관계를 구축하고 상호 격려를 통해 상호 관심사항을 파악 및 분석하고 파트너십 내부에 권력을 적절히 배분하고 출구 전략에 대한 고려도 이루어 져 야 한다.

결론적으로, $\mathrm{ODA}$ 와 $\mathrm{CSR}$ 의 효과적인 연계를 위해서는 민간부문과의 파트너십 구축을 위한 구체적인 전략과 정책 제시가 필요하다. 국내 기업의 $\mathrm{ODA}$ 에 대한 인식 부족 및 $\mathrm{ODA}$ 와 $\mathrm{CSR}$ 활동의 연계 가능성에 대한 인식 부족을 해소하기 위해 더욱 노력해야 한다. 그리고 기업에 대 한 지원 범위와 목적을 명확히 하여 불필요한 오해나 반감을 불러일으키지 않는 것이 필요하다. 나아가서는 우리나라 ODA의 중점협력국을 대상으로 한 연구, 조사 등을 통해 효과적인 CSR과 $\mathrm{ODA}$ 의 연계 사업개발이 시급하다. 한국의 경우 신흥공여국이며 민간부문에 대한 지원이 초기 단계인 점을 고려해 다양한 방식과 협력 모델을 고안하여 시도하고 평가하는 것이 필요하다. 궁 극적으로는 개별 기업과의 연계를 넘어서 공급 사슬 전체에 대한 파트너십 등 보다 포괄적이고 효과적인 Multi-Stakeholder Initiative도 시도해 볼만 하다.

지금까지 논의된 사항을 바탕으로 지속가능한 발전을 위해 인식제고 및 인프라 구축이 선행되 고 각종 지원방안이 마련되어야 할 것이다. 특히 지속가능한 발전을 위한 사회전반의 공감대를 형성할 수 있는 협력적 네트워크를 구성하여 정보 및 노하우를 공유할 수 있는 공조체제 수립이 필요하다. 따라서 다양한 이해관계자들의 의견을 수렴하여 공동의 합의점을 도출하고 발전방향 을 모색하는 민관협의체에 대한 논의와 지속가능한 발전을 위한 정보교환이 가능한 정보 플랫 폼에 대한 논의도 필요하다. 이처럼, 정부의 $\mathrm{ODA}$ 예산 확대와 부산 글로벌 파트너십 체계 이행 을 위해서는 향후 다양한 민간 파트너와의 협력을 통해 ODA 방식을 다변화하고, 이를 통해 개 발협력을 보다 효율적이고 효과적으로 이행할 필요성이 대두되고 있다.

한국은 2010년 서울 G20 정상회의 및 2011년 부산세계개발원조총회에서 국제사회가 합의한 사항 을 국내 $\mathrm{ODA}$ 체제에 반영할 수 있어야 할 것이다. 즉, 국제사회의 지속가능한 발전을 위해서는 정부 뿐 아니라 민간부분 및 시민사회의 국제개발협력 참여가 필수적이라는 점을 고려해야 한다.

이러한 측면에서, 국제개발협력에 직·간접으로 기여하는 국내 기관간 네트워크를 구축한다 면 상호 정보 공유 및 시너지 효과를 창출할 수 있을 것으로 기대한다. 그간 $\mathrm{KOICA}$ 는 NGO 
기업 - 대학 등 각각의 민간 파트너와의 제한적 협력을 통해 소규모로 사업을 추진해 왔다면 앞 으로는 보다 큰 프레임워크로 협력의 장을 확대하여 추진해야 할 것이다. 결국, 개발협력연대와 같은 공공-민간간 개발협력 논의의 장을 마련하여 공동 민관협력 사업을 추진하는 방안을 제기 해 본다. 


\section{참고문헌}

\section{1. 국내문헌}

곽재성 (2012). 국제개발과 민관협력, 이슈와 정책제언. 국제개발협력 제 1 호. 한국국제협력단. 김성규 (2012). 사회적 기회 및 안전망 확대와 개발협력. 국제개발협력 제2호. 한국국제협력단. 이계우 (2009). 한국의 국제개발원조 조달시장 진출정책. 국제개발협력 제4호. 한국국제협력단. 이부키 에이코 (2006). 사랑받는 기업의 조건. 메일경제신문사.

이성훈 (2011). 시민사회가 바라보는 부산총회의 성과와 향후 과제. 국제개발협력 제4호. 한국국제협력단.

이성훈 (2012). 국제개발협력과 시민사회(CSO)의 역할 : 부산총회 이후의 맥락에서. 국제개발 협력 제 1 호. 한국국제협력단.

임소진 (2011). 부산 세계개발원조총회의 성과와 한국 ODA의 과제. 개발협력 정책과 이슈 제 3 호. 한국국제협력단.

임소진 (2012a). 부산파트너십 이행 평가지표 수립방향 및 전략연구. KOICA 개발정책 포커스 제10호. 한국국제협력단.

임소진 (2012b). 한국 ODA의 부산 글로벌 파트너십 평가지표 이행방안. $\mathrm{KOICA}$ 개발정책 포커스 제 15 호. 한국국제협력단. (출판예정)

\section{2. 국외문헌}

Buckland, H. et al. (2006). The changing role of government in corporate responsibility. Literature Review. EABIS.

Hopkins, M. (2007). Corporate Social Responsibility and International Development: Is Business the Solution? London, Earthscan.

Miles, P. and J. Covin (2000). Environmental marketing: A source of reputational, competitive, and financial advantage. Journal of Business Ethics. 23(3). 299-311. 
OECD (2011). Aid Effectiveness 2005-10: Progress in Implementing the Paris Declaration.

Van Marrewijk, M. (2003). Concepts and Definitions of CSR and Corporate Sustainability. Journal of Business Ethics. 44(2/3). 95-105.

Zadek (2001). The Civil corporation : The new economy of corporate citizenship. London, Earthscan. 